\title{
Effects of alphamune $g$ on the performance, serum and haematological parameters of Escherichia coli challenged turkey poults
}

Bolu S.A. and Adelakun, M.T.

Dept of Animal Production, University of Ilorin, Ilorin, Nigeria. bolusao2002@yahoo.co.uk.

\begin{abstract}
A study was conducted to determine the response of Turkey poults to graded levels of Alphamune $G$ $(0.00+, 0.03,0.04,0.05,0.06$ and $0.00 \%-)$ when challenged with Escherichia coli orally for 7 days. The graded levels were the treatments viz $0.00 \%+$ (positive control), Alphamune $G$ at 0.03, 0.04, $0.05,0.06 \%$ and $0.00 \%$ - (negative control; infected without Alphamune G supplementation). Each treatment was allotted 3 replicates of 6 poults. The experiment which was conducted for 56 days employed a completely randomized design. E. coli was isolated from the intestinal digesta of a colisepticaemic chicken. 108 turkey poults were used in this study. Poults were infected with E.coli for 7 days through the drinking water and given the treatment. The performance parameters of Alphamune $G$ supplementation were significantly affected. The cumulative weight, Feed intake and weight gain were highest for turkey poults fed 0.06\% Alphamune G supplementation. These values were also directly proportional to the supplementation levels of Alphamune G. The birds given the negative treatment $(0.00 \%$-) had relatively poor performance compared to the other treatments. The specific enzymes studied were significantly affected $(p<0.05)$ by the treatments. ALT and AST were significantly highest for turkey poults fed the negative control. Enzyme values became optimum at $0.05 \%$ Alphamune $G$ supplementation. At $0.06 \%$ of Alphamune $G$ supplementation, cellular mitigations of the effects of E. coli was measurable. Urea and creatinine were not significantly $(p>0.05)$ influenced by the treatments. Haematological indices such as WBC and specific differential counts (lymphocytes and neutrophils) were affected significantly $(P<0.05)$ by supplemental levels of Alphamune $G$ The Inclusion of Alphamune $G$ at $0.06 \%$ in the diets improved performance of turkey poults when challenged with Escherichia coli.
\end{abstract}

Keywords: alphamune g, performance, blood parameters, Escherichia coli, turkey poults

\section{Introduction}

Ahild et al., 2001).

There are a number of potential immunentibiotics are used mainly to protect poultry from pathogenic organisms, enhance their growth and health. However, the emergence of antibiotic resistance by pathogenic bacteria has led to international reconsideration of the use of antibiotics in livestock feeds (Thwaites and Frost, 1999; Bywater, 2005). Early concerns about the development of antibiotic resistance in human pathogens and recommendations to ban subtherapeutic use in animal feeds have been documented (Castanon, 2007; Dibner and Richards, 2005).

It has been reported that antibiotic resistance of $E$. coli of poultry has remained at a relatively high level since the 1950s (Gustafson and Bowen, 1997). Antibiotic Growth Promotion (AGP) has been practiced for about 50 years in many countries. In addition, subtherapeutic antibiotics have been used to enhance gastrointestinal maturity (Dibner and Richards, 2005). Antibiotic resistance has been displayed by Escherichia coli isolates from commercial turkey farms, including resistance to Enroßoxacin, one of the most recently approved antibiotics for 
use in poultry (Faircmodulators that may serve as alternatives to antibiotics for both growth promotion and disease resistance in turkey production. The ß-glucans are polymers of glucose that can be derived from the cell walls of yeast, bacteria, fungi, and cereals such as oats, barley, and rye. They have been found to increase the functional activity of macrophages and neutrophils (Reynolds et al., 1980; Yun et al., 2003). Mannan-oligosaccharides are polysaccharide-protein complexes derived from yeast that are indigestible to nonruminant animals can function as prebiotics, providing favourable conditions for beneficial intestinal Lactobacillus spp. (Flickinger and Fahey, 2002). They also provide competitive binding sites for pathogens with mannose-specific fimbriae such as Salmonella, causing them to pass through the intestine, thus decreasing attachment and colonization(Sims et al., 2004; Zdunczyk et al., 2002) and improve feed conversion efficiency in turkeys grown to 20 week (Fritts and Waldroup, 2003). Alphamune is an alternative to Antibiotics Growth Promoter (AGP) (Alpharma Animal Health, 2004; Alpharma, 2011). Alphamune is an extract of Saccharomyces cerevisae that has been spray dried to a tan powder and granulated (Bolu et al. 2011). It is a feed supplement that improves performance and immuno-competence system of animals. It enables the animal withstand occurring pressure within its own physiological competence (Huff et al, 2006). Alphamune $\mathrm{G}$ is a combination of 1 3, $1-6 \beta$ glucans and mannan oligosaccharides. $\beta$-Glucan has been found to possess immunomodulatory function and mannans, a prebiotic effect within the biological systems (Bent and Jesen, 2000). It has been reported that Alphamune $G$ supplementation in pig diet improved performance when compared to salinomycin (an AGP). Optimal performance of Alphamune has been recorded at $500 \mathrm{~g}$ /tonnes of feed for broiler chicks (Alpharma Animal Health, 2004).

This study was conducted to determine the performance serum and haematological parameters of Escherichia coli-challenged turkey poults fed Alphamune $\mathrm{G}$ based diets.

\section{Materials and Methods Study Area}

The experiment was carried out in the Animal Pavilion of the Department of Animal Production, University of Ilorin (80 $\left.28^{\prime} 0 \mathrm{~N}, 4^{0} 41^{\prime} 0 \mathrm{E}\right)$, Ilorin, Nigeria.

\section{Experimental Birds}

One hundred and eight, four (4) week old poults were obtained from a commercial hatchery. The poults were weighed and randomly allotted to 6 treatments. Each treatment was replicated three times consisting of 6 poults per replicate raised in metabolic battery cages. A basal diet was formulated to contained 2,900 kcal of $\mathrm{ME} / \mathrm{kg}$ and $26.0 \% \mathrm{CP}$ to meet the nutrient requirement of young poults (NRC, 1994).The dietary treatments (Table 1) consisted of 6 supplemental levels of Alphamune $\mathrm{G}(0.00 \%+, 0.03 \%, 0.04 \%$, $0.05 \%, 0.06 \%$, and $0.00 \%$ - per $100 \mathrm{~kg}$ of feed). The graded levels were the treatments viz; $0.00 \%+$ (positive control), Alphamune $\mathrm{G}$ at $0.03,0.04,0.05,0.06 \%$ and $0.00 \% \%^{-}$(negative control; infected without Alphamune G supplementation).

\section{Source of $E$. coli}

Escherichia coli were isolated from chickens with colisepticemia. Samples of the intestinal digesta were collected with sterile cotton swab. The inoculum was prepared by adding 2 inoculating loops of the sample on blood agar to $100 \mathrm{ml}$ of Tryptose Phosphate Broth (TPB) and incubating for $2.5 \mathrm{~h}$ in a $37^{\circ} \mathrm{C}$ sonicator 
water bath. Escherichia coli colony was identified by a distinctive dark with metallic green sheen colour. A sterile needle was used to retreak an overnight culture Escherichia coli new culture plate to obtain pure cultures. The culture was incubated overnight at $4^{\circ} \mathrm{C}$ while a standard plate count was made. Ten-fold dilutions were then made in TPB based on the standard plate count and the challenge dilution titre equivalent to $1.23 \times 10^{8} \mathrm{cfu} /$ poult (Sarkozy et al, 2000) was verified with another plate count. The poults were challenged via the dilution for a period of 7 days in drinking water. Turkey poults in treatments $2,3,4,5$ and 6 were challenged with Escherichia coli.

Routine management and vaccination were followed. Feed and water were given ad libitum for the 56 days of feeding trial. The basal diet contained 2,900 kcal of ME $/ \mathrm{kg}$ and $28.0 \% \mathrm{CP}$ which were in accordance with NRC recommended allowances (NRC, 1994).

Data were collected daily on feed intake and weight gain. Feed:gain was computed from the data of daily feed intake as a ratio of weight gain. At the end of the third week of study, a nitrogen retention study was conducted. Feed was weighed and given to birds and feacal samples collected over a period of 72 hours employing total collection method. Feacal samples collected were oven-dried, ground and analyzed for proximate composition. Proximate compositions of feed and feacal samples were carried out using the methods ofAOAC (1990)

At four weeks of the study, blood samples were randomly taken from the wing veins of four (4) birds from treatment across replicates into bijou bottles containing EDTA (anticoagulant). Packed cell volume (PCV), haemoglobin concentration, total $\mathrm{RBC}, \mathrm{WBC}$ and differential counts were evaluated according to Dacie and Lewis (1997). Serological samples were taken from collected blood (without anticoagulant), centrifuged at $4000 \mathrm{rpm}$ for $3 \mathrm{~min}$. and the supernatant sera harvested in bijou bottles for the determination of specific serum biochemical indices. Enzyme assay for serum aspartate amino transferase (AST, EC 2.6.1.1) and alanine amino transferase (ALT, EC 2.6.1.2) were determined by the colorimetric method of Reitman and Frankel (1957) while alkaline phosphatase (AP, EC 3.1.1.3) was determined by the kinetic method of Frajola et al. (1965).. Response criteria were subjected to analysis of variance (ANOVA) using the SAS statistical package (SAS, 1985). Differences between treatment means were separated using Duncan multiple range test (Duncan, 1955).

\section{Results and Discussion}

The performance parameters of Alphamune $\mathrm{G}$ supplementation were significantly affected (Table 2). The cumulative weight, Feed intake and weight gain were highest for turkey poults fed $0.06 \%$ Alphamune $G$ supplementation. As the levels of Alphamune $\mathrm{G}$ increased, the body weights also increased. The values for all performance parameters measured for birds given the negative treatment $(0.00 \%$-) were comparatively low. Nitrogen retained was significantly influenced by Alphamune $G$ supplementation of $E$. coli challenged poults. Poults fed the negative control diet recorded the lowest value for nitrogen retained. Results of the performance suggest that Alphamune $G$ may have mitigated the adverse effects of E.coli (toxaemia) on the poults. These mitigations are voluntary feed intake and subsequently rapid muscle development cumulating to $5.20 \mathrm{~kg}$ for poults fed $0.06 \%$ Alphamune G supplementation. Saif, 
Effects of alphamune $G$ on the performance and blood parameters of Escherichia coli challenged turkey poults

Table 1. Composition of Experimental Treatments

\begin{tabular}{lccl}
\hline Diet & $\begin{array}{l}\text { Infected with } E . \\
\text { coli }\end{array}$ & $\begin{array}{l}\text { Supplemented with } \\
\text { Alphamune } \\
(\%)\end{array}$ & Treatment \\
\hline 1 & - & - & Positive control \\
2 & + & 0.03 & $0.03 \%$ \\
3 & + & 0.04 & $0.04 \%$ \\
4 & + & 0.05 & $0.05 \%$ \\
5 & + & 0.06 & $0.06 \%$ \\
6 & + & - & Negative control
\end{tabular}

Basal diet contained(\%); Corn, 34.74; SBM, 9.15; GNC, 18.29; Fish meal, 12.85; Wheat offal, 13.41; Bone meal, 2.00; Lysine, 0.30; Methionine, 0.30; Salt, 0.30 and Vitamin/Mineral Premix** 0.30. Analysed Nutrient Content (\%): DM, 90.98; CP, 26.00; EE, 6.65; CF, 3.60; Ash, 5.40 .

**Premix supplied per kg of diets; Vitamin A: 8x10 IU, Vitamin D3: 1500IU, Vitamin E: 10IU, Vitamin ${ }_{3}: 1.5 \mathrm{mg}$, Vitamin B1: 1.6mg, Vitamin $\mathrm{B}_{2}: 4 \mathrm{mg}$, VitaminB6: 1.5mg, Vitamin B12:0.0mg, Niacin: 20mg,Pantothenic acid: $5 \mathrm{mg}$, Folic acid: $0.05 \mathrm{mg}$, Biotin:0.75mg, Choline Chloride: $1.75 \times 10^{4} \mathrm{mg}$, Cobalt:0.2mg, Copper: $0.2 \mathrm{mg}$, Iodine: $1 \mathrm{mg}$, Iron: $20 \mathrm{mg}$,Manganese: $40 \mathrm{mg}$, Selenium: $0.2 \mathrm{mg}$, Zinc: $80 \mathrm{mg}$,Antioxidant: $1.25 \mathrm{mg}$.

(2003); Austic and Nesheim, (1990) observed that the major clinical signs of colibacilosis include ill-thrift, ruffled feathers, enlarged and swollen navel, decreased appetite (anorexia), depression, diarrhea and pasting of feathers around vent. The increased voluntary feed intake, weight gain and nitrogen retained in proportion of supplemental levels of Alphamune $G$ suggests that dietary Alphamune-G may have aided nutrient digestion, especially energy. NRC (1994) observed that feed intake in poultry is inversely related to the energy content of the diet. Through a feedback mechanism, energy satiety can reduce voluntary feed intake. When compared to the negative control poults, Alphamune G proportionally enhanced the efficiency of feed conversion culminating in relatively higher weight gains. Bolu et al., (2009) reported that dietary Alphamune at $0.04 \%$ and $0.05 \%$ improved the performance of broilers. These findings also corroborates the reports of Miles and Bootwalla, (1991); Madrigal et al., (1993); Bradley et al., (1994); Santin et al., (2001). This improvement may be related with the balanced microbial population in the gastrointestinal tract (prebiotic effect) which has an important role in the health and performance of the broilers (Santin et al, 2001). Cumulative weight gain is a function of nutrition; Alphamune-G and other yeast cell complex have been shown 
to improve feed conversion efficiency, nitrogen retetion and increased body weight in chickens (Bolu et al., 2009; Zhang et al., 2005). Broilers chicks fed $0.04 \%$ dietary inclusion of Alphamune $G$ gave the best performance (Bolu, et al., 2009).

The specific enzymes studied were significantly affected $(\mathrm{p}<0.05)$ by the treatments (Table 3). ALT and AST were significantly highest for turkey poults fed the negative control. The trend for these enzymes in relation to Alphamune $G$ supplementation suggests that there was a proportionate rise in the values obtained for the enzymes with increasing levels of supplementation. However, the rise in the enzyme values became optimum at $0.05 \%$ Alphamune G supplementation. At $0.06 \%$ of Alphamune $\mathrm{G}$ supplementation, cellular mitigations of the effects of $E$. coli was measurable; the values observed for these enzymes were less. ALP was significantly influenced by the treatments, although most of the values are within the range for turkey poults (MVM,1986). Poults fed the positive control had low value for ALP. Increasing levels of Alphamune $G$ tended to increase ALP value similar to the other enzymes. However, the level of this enzyme reported for poults fed $0.06 \%$, suggest mitigated effects of E. coli. According to Otesile et al., (1991); Kecceci et al., 1998 serum biochemistry is a generalized medium of assessing the health status of animals. Blood parameters are potent indices of physiological, pathological and nutritional status of an organism (Babatunde and Olusanya, (1992). Changes in blood constituent are indirect indices to assess the metabolic stage of an animal as well as quality of feed. Prescott and Baggot (1993) reported that growth promoters perform best when the animal is in poor health and unhygienic living condition; thus, challenging the poults with E. coli enhanced the immunomodulatory effects of

Table 2 Effects of Graded Levels of Alphamune G on Performance of Turkey Poults

\begin{tabular}{|c|c|c|c|c|c|c|c|}
\hline \multirow{2}{*}{ Parameters } & \multicolumn{5}{|c|}{ DIETS } & \multirow[b]{2}{*}{6} & \multirow{2}{*}{ \pm SEM } \\
\hline & 1 & 2 & 3 & 4 & 5 & & \\
\hline $\begin{array}{l}\text { Av. Initial } \\
\text { weight (kg) }\end{array}$ & 0.96 & 0.95 & 0.97 & 0.95 & 0.94 & 0.97 & \\
\hline $\begin{array}{l}\text { Av. Final } \\
\text { weight (kg) }\end{array}$ & $5.81^{\mathrm{bc}}$ & $4.75^{\mathrm{a}}$ & $5.17^{\mathrm{ab}}$ & $5.55^{\mathrm{b}}$ & $6.14^{\mathrm{c}}$ & $4.57^{\mathrm{a}}$ & 0.42 \\
\hline $\begin{array}{l}\text { Cumulative } \\
\text { weight (kg) }\end{array}$ & $4.85^{\mathrm{bc}}$ & $3.80^{\mathrm{a}}$ & $4.20^{\mathrm{ab}}$ & $4.60^{\mathrm{b}}$ & $5.20^{\mathrm{c}}$ & $3.60^{\mathrm{a}}$ & 0.48 \\
\hline $\begin{array}{l}\text { Weight } \\
\text { g/bird/day }\end{array}$ & $86.61^{\mathrm{c}}$ & $67.86^{\mathrm{a}}$ & $75.00^{\mathrm{b}}$ & $73.21^{\mathrm{b}}$ & $92.85^{\mathrm{d}}$ & $64.28^{\mathrm{a}}$ & 4.53 \\
\hline $\begin{array}{l}\text { Feed intake } \\
\text { g/bird/day }\end{array}$ & $167.4^{\mathrm{b}}$ & $151.24^{\mathrm{a}}$ & $184.95^{\mathrm{c}}$ & $189.49^{c}$ & $200.14^{d}$ & $172.58^{\mathrm{b}}$ & 9.40 \\
\hline Feed: gain & $1.94^{\mathrm{a}}$ & $2.18^{\mathrm{b}}$ & $2.46^{\mathrm{c}}$ & $2.59^{\mathrm{d}}$ & $2.16^{\mathrm{b}}$ & $2.68^{\mathrm{e}}$ & 0.08 \\
\hline $\begin{array}{l}\text { Nitrogen } \\
\text { retained } \\
(\%)\end{array}$ & $68.12^{\mathrm{c}}$ & $60.14^{\mathrm{b}}$ & $64.56^{c}$ & $65.55^{\mathrm{c}}$ & $67.62^{c}$ & $52.34^{\mathrm{a}}$ & 4.35 \\
\hline
\end{tabular}


Aplhamune G supplementation. Enzymes are protein catalysts present mostly in living cells that are constantly and rapidly degraded although, renewed by new synthesis (Coles, 1986). According to Zilva and Pannall (1984), normal enzyme level in serum is a reflection of a balance between synthesis and their release as a result of the different physiological processes in the body. These enzymes measured in this study are found predominantly in the hepatocytes and renalocytes. However, during condition that may predispose liver and kidney damage, these enzymes are found abundantly in the blood (Bolu et al, 2008). In the same vein, Keele and Neil (1971) reported that serum AST is significantly high under disease and morbid conditions (as we have in the negative controlled poults) involving injuries to large numbers of metabolically active cells. Shipman et al (2013) reported that ALP are predominantly found in the liver, bone, kidney, intestine and placenta, however, circulating ALP are hepatic and the bone. Liver damage can be indirectly detected with ALP values at interval. Urea and creatinine were not significantly $(\mathrm{p}>0.05)$ influenced by the treatments (Table 3). Creatinine is a waste product of muscle metabolism and a good measure of kidney function (Siamak, 2011). The values of the serum creatinine and urea are indicative of kidney condition.

Haematological indices such as WBC and specific differential counts (lymphocytes and neutrophils) were affected significantly $(\mathrm{P}<0.05)$ by supplemental levels of Alphamune G (Table 3). There was significant rise in these values for turkey poults fed the negative control diets in response to $E$. coli challenge. The unchallenged bird had the least values. Alphamune $\mathrm{G}$, a prebiotic have relatively reduced the immunologic response to $\mathrm{E}$. coli challenge, resulting in the significantly low values of these cell mediated products comparable to the unchallenged poults. White blood cells in the avian species perform phagocytic functions similar to their mammalian counterparts (Campbell and Coles, 1986) and are used as indicators of stress response and sensitive biomarkers crucial to immune function (Shaniko, 2003). Leucocytes values of indigenous chickens have been reported to be higher than those of exotic breeds, lending credence to their higher susceptibility to avian pathogenic agents (Uko and Ataja, 1996; Talebi et al., 2005). Heterophils are the most abundant leukocyte in the peripheral blood of most species of birds in most studies, whereas some avian species are lymphocytic (have lymphocytes as the predominant cell type in the differential count) (Fudge, 2000; Latimer et al, 1988). The turkeys in this study had lymphocyte as the most abundant leukocyte in the peripheral blood further corroborating earlier works (Bolu, et al 2009, 2011 and 2012). Hematological studies of wild turkeys showed a similar condition (Bounous et al., 2000). Bounous et al (2000) reported that the lymphocytes are the predominant leukocyte in the peripheral blood of chickens and turkeys. That the Lymphocyte values were higher in birds fed Alphamune $\mathrm{G}$ inclusion than in control with the least value (62\%) further attested to the immunomodulatory function of Alphamune $\mathrm{G}$ by conferring high immunity in the poults (Bolu et al, 2012; Adeyemo and Longe, 2007).

\section{Conclusion}

The results of this study suggest that Alphamune $\mathrm{G}$ supplementation at $0.06 \%$ enhanced the performance and blood parameters of $E$. coli challenged poults and could effectively substitute for antibiotic 
Table 3 Effects of graded levels of Alphamune-G on Serum and Haematological Parameters of Escherichia Coli Challenged Poults.

\begin{tabular}{|c|c|c|c|c|c|c|c|}
\hline \multirow[t]{2}{*}{ PARAMETERS } & \multicolumn{6}{|c|}{ DIETS } & \multirow[t]{2}{*}{$\begin{array}{c}\text { SEM } \\
\pm\end{array}$} \\
\hline & 1 & 2 & 3 & 4 & 5 & 6 & \\
\hline $\begin{array}{l}\text { Alanine Aminotransferase } \\
\text { (iu/l) }\end{array}$ & $19.40^{\mathrm{a}}$ & $24.20^{\mathrm{a}}$ & $26.50^{\mathrm{a}}$ & $28.40^{\mathrm{a}}$ & $25.90^{\mathrm{a}}$ & $33.50^{\mathrm{b}}$ & 9.23 \\
\hline $\begin{array}{l}\text { Aspartate Amino } \\
\text { Transferase(iu/l) }\end{array}$ & $104.60^{\mathrm{a}}$ & $113.30^{\mathrm{a}}$ & $98.50^{\mathrm{a}}$ & $124.20^{\mathrm{b}}$ & $120.70^{\mathrm{ab}}$ & $126.0^{\mathrm{b}}$ & 10.06 \\
\hline $\begin{array}{l}\text { Alkaline Phosphatase } \\
(\mathrm{iu} / \mathrm{l})\end{array}$ & $40.40^{\mathrm{a}}$ & $36.90^{\mathrm{a}}$ & $48.30^{b}$ & $46.00^{\mathrm{b}}$ & $40.60^{\mathrm{a}}$ & $43.00^{\mathrm{b}}$ & 6.22 \\
\hline Urea(Mmol/l) & 6.30 & 9.20 & 9.20 & 10.10 & 9.80 & 9.60 & 4.38 \\
\hline Creatinine(Mmol/l) & 0.70 & 1.00 & 1.30 & 1.20 & 1.90 & 2.50 & 2.11 \\
\hline Packed Cell Volume (\%) & 26.90 & 24.00 & 27.00 & 28.00 & 28.00 & 28.00 & 4.68 \\
\hline Haemoglobin(g/dl) & 7.60 & 6.50 & 6.80 & 6.30 & 6.60 & 6.80 & 2.21 \\
\hline White Blood Cell( $\left.\times 10^{9} / 1\right)$ & $7.00^{\mathrm{a}}$ & $8.40^{\mathrm{a}}$ & $7.60^{\mathrm{a}}$ & $7.80^{\mathrm{a}}$ & $8.30^{\mathrm{a}}$ & $10.50^{\mathrm{b}}$ & 1.35 \\
\hline Red Blood Cell(x10 1 /1) & 5.80 & 5.00 & 5.90 & 4.80 & 5.60 & 5.90 & 1.21 \\
\hline Lymphocyte (\%) & $62.00^{\mathrm{a}}$ & $63.00^{\mathrm{a}}$ & $70.00^{\mathrm{b}}$ & $65.00^{\mathrm{ab}}$ & $69.00^{\mathrm{b}}$ & $64.93^{\mathrm{ab}}$ & 4.91 \\
\hline Neutrophil (\%) & $30.00^{\mathrm{a}}$ & $37.00^{\mathrm{c}}$ & $30.00^{\mathrm{a}}$ & $35.00^{\mathrm{a}}$ & $30.00^{\mathrm{a}}$ & $45.00^{\mathrm{b}}$ & 7.82 \\
\hline Eosinophils (\%) & 0.00 & 0.00 & 0.00 & 0.00 & 0.00 & 1.00 & 3.17 \\
\hline Monocytes (\%) & 0.00 & 0.00 & 0.00 & 0.00 & 0.00 & 0.00 & 0.06 \\
\hline Basophils (\%) & 0.00 & 0.00 & 0.00 & 0.00 & 0.00 & 0.00 & 0.00 \\
\hline
\end{tabular}

growth promoter.

\section{References}

Adeyemo, G.O. and O.G. Longe, 2007. Effect of graded levels of cotton seed cake on performance, haematology and carcass characteristics of broiler fed from day old to 8 weeks of age. Afr. J. Biotechnol., 6: 1064-1071.

Alpharma Animal Health, 2004. Alphamune G. for poultry. http://www.thepoultrysite.com/article s/722/ alphamune-g-data-sheet.

Alpharma Animal Health. 2011. http://www.
alpharmaahd.com/Alphamune/Intro.h tm

AOAC 1990. Official methods of Analysis. Association of Official Analytical Chemists. $15^{\text {th }}$ edition Washington D.C. pp1094

Austic R.and C. Nesheim, 1990. Poultry Production (13th Edition); Lea \& Febiger Publishers.

Babatunde, G.M. and A.Olusanya. 1992. Rubber seed oil vs. palm oil in broiler chickens diet. Effect on performance, nutrient digestibility, haematology and carcass characteristics. Feed. Sci. Technol., 35: 133146.

Bent, B. and B.B. Jessen. 2000. Possible 
Effects of alphamune $G$ on the performance and blood parameters of Escherichia coli challenged turkey poults

ways of modifying type and amount

of products from microbial

fermentation in the gut. 8 th

Symposium on Digestive Physiology

in Pigs. Workshop on: Gut

Environment. Influence of luminal

factors, Uppsala, Sweden, 19 June, page 12-14

Bolu, S.A., S. Olakotan, A. Elkanah and

F. Soyemi 2008. Response of Broiler chicks to supplementation of

LIVELONG (a commercial growth

promoter-cum-immunomodulator).

Indian Journal of Animal Nutrition

and Feed technology. 8 (2): 237 - 244

Bolu, S.A., V. Ojo, B.A. Oyeleke, A.O. Ajiboye, A. Baa Sambo and $O$. Oluyemi, 2009. Effects of Alphamune $G$ on the performance, blood chemistry and Histology of Broilers. Int. J. Poult. Sci., 8: 32-34.

Bolu S. A. O., I. Alli, O. Oluyemi, O.B. Olanigan and O.J. Akinsanya. 2011. Response Of Turkey Poults To G r a d e d L e v e l s O f Alphamune.Research Opinions In Animal \& Veterinary Sciences Issn 2221-1896. Www.Roavs.Com

Bolu, S. A. Adeyemi, K. D. Sola-Ojo, F. E. Fabiyi, A. A. Adedeji, A. T. Oluyemi $O$. and

A. B. Babalola 2012. Lower Dietary Inclusion of Alphamune $G$ May Improve Performance, Hematology, Serum Biochemistry and Histology of Broiler Chicken. Sustainable Agriculture Research Vol. 1, No. 2: 1520 doi:10.5539/sar.v1n2p15 URL: http://dx.doi.org/10.5539/sar.v1n2p15

Bounous D.I., R.D. Wyatt, P.S. Gibbs, J.V. Kilburn and F.C. Quist. 2000. Normal Hematologic and Serum Biochemical Reference Intervals for Juvenile Wild Turkeys. Journal of
Wildlife Diseases, 36(2): 393-396.

Bradley, G. L., T. F. Savage and K. I. Timm, 1994. The effects of supplementing diets with Saccharomyces cerevisiae var. boulardii on male poultry performance and ileal morphology. Poult. Sci., 73: 1766-1770.

Bywater, R. J. 2005. Identification and surveillance of antimicrobial resistance dissemination in animal production. Poult. Sci. 84:644-648.

Campbell, T.W. and E.H. Coles, 1986. Avian clinical pathology. In: Coles, E.H. (Ed.), Veterinary Clinical Pathology. 4 Edition. Saunders Co., Philadelphia, th Galindo-Muniz, F., N.L. Calderno, M.N. Charles, I.G.

Castanon J. I. R. 2007. History of the Use of Antibiotic as Growth Promoters in European

Poultry Feeds. Poult Sci. 86:2466-2471; doi:10.3382/ps.2007-00249

http://ps.fass.org/content/86/11/246 6.abstract. accessed 04/09/2003

Coles, E.H., 1986. Veterinary Clinical Pathology of Domestic Animals. 2 ed. Academic Press, New York, USA.

Dacie J.W. and Lewis, S.M. 1977. Practical Haematology. 5th ed. Longman Group Ltd. London, UK, pp. 21-68.

Dibner, J. J. and J. D. Richards 2005. Antibiotic growth promoters in agriculture: History and mode of action. Poult. Sci. 84:634-643.

Duncan, D.B., 1955. Multiple range and multiple F test Biom., 11: 1-42.

Fairchild, A. S., C.W. Parks, J.L. Grimes, and P.R. Ferket. 2001. "The effect of mannanoligos a c harides, bambermycins, and virginiamycin on

Flickinger E.A., and G.C. Fahey Jr 2002. Pet food and feed applications of inulin, oligofructose, and other 
oligosaccharides. Br. J. Nutr., 87: S297-S300.

Frajola, W.J., R.D. William and R.A. Austin, 1965. The kinetic spectrophotometric assay for serum alkaline phosphatase. American Journal of Clinical Pathology, 43: 261-264.

Fritts C.A. and P.W. Waldroup. 2003. Effect of source and level of Vitamin $\mathrm{D}$ on live performance and bone development in growing broilers. $J$. Appl. Poult. Res. 12: 45-52

Fudge, A.M., 2000. Laboratory MedicineAvian and Exotic Pets. W.B. Saunders Company, Philadelphia, pp:486.

Gustafson, R.H. and R.E. Bowen 1997. Antibiotic use in animal agriculture. $J$. Appl. Microbiol. 83:531-541

Huff, G., W. Huff, N. Rath, J. Balog, N. B. Anthony, and K. Nestor. 2006. Stressinduced colibacillosis and turkey os teomyelitis complex in turkeys selected for increased body weight. Poult. Sci. 85:266-272.

Kecceci, T., H. Oguz, V. Kurtoglu and $O$. De m e t, 1998. E f f e c t of polyvinylpyrrolidon, synthetic zeolite and bentonite on serum biochemical and haematoogical characteristics of broiler chickens during aflatoxicosis. Br. Poult. Sci., 39: 152-158.

Keele, C. A. and E. Neil, 1971.Samson Wrights Applied Physiology. $12^{\text {th }}$ Edition, ELBS and OUB, London. 576pp.

Latimer, K.S., T.N. Tang and M.A. Goodwin, 1988. Leukocyte changes associated with acute inflammation in chickens. Avian Dis., 32: 760-763.

Madrigal, S. A., S. E. Watkins, J. T. Skinner, M. H. Adams, A. L. Waldroup and D. W. Waldroup, 1993. Effect of an active yeast culture on performance of broilers. Poult.
Sci., 72 (Suppl 1), 87(Abstr.).

Miles, R. D. and S. M. Bootwalla, 1991. DirectFed Microbials in Animal Production- A review of the Literature. National Feed Ingredients Association, West Des Moines, IA. Direct-fed microbials in animal production "avian". pp. 117-146. Newman, K., 1994. Biotechnology in the Feed Indus

MVM, 1986. Merck Veterinary Manual. 6th Edn. Merck and Co. Wc Rehway NJUSA, pp: 1-9.

National Research Council. 1994. Nutrient Requirements of Poultry. National Academy Press, Washington, DC.

Otesile, E.B., B.O. Fagbami and O. Adeyemi, 1991. The effect of Trypanosoma brucei infection on serum biochemical parameters in boars on different planes of dietary energy. Vet. Parasit., 40: 207-216.

Prescott, J.F. and J.D. Baggot, 1993. Antimicrobial Therapy Veterinary Medicine. 2nd Edn. IOWA State University Press, pp: 564-565.

Reitman, S. and A. Frankel, 1957. Method of transaminase determination in serum. Journal of ClinicalPathology, 28: 56-59.

Reynolds, J. A., M. D. Kastello, D. G. Harrington, C. L. Crabbs, C. J. Peters, J. V. Jemski, G. H. Scott, and N. R. Di Luzio. 1980. Glucan-induced enhancement of host resistance to selected infectious diseases. Infect. Immun. 30:51-57.

Saif, M. (ed.), 2003. Disease of Poultry:; Iowa State University Press.

SAS. 1985. SAS Users Guide Statistics. SAS Institute, Cary, NC.

Santin, E., A. Maiorka, M. Macari, M. Grecco, J. C. Sanchez, T. M. Okada and A. M. Myasaka, 2001. Performance and intestinal mucosa 
Effects of alphamune $G$ on the performance and blood parameters of Escherichia coli challenged turkey poults

development of broiler chickens fed diets containing Saccharomyces cerevisiae cell wall. J. Appl.

Sárközy, G, G. Semjén, P. Laczay, E. Horváth, and J. Schmidt. 2002.Pulse and continuous oral norfloxacin treatment of experimentally induced Escherichia coli infection in broiler chicks and turkey poults. Acta Vet Hung. 2002;50(2):199-210.

Shaniko, S., 2003. Physiological responses of laying hens to the alternative housing systems. Int. J. Poult. Sci., 2: 357-360.

Shipman, K.E, A.D. Holt and R. Gama. 2013. Interpreting an isolated raised serum Alkaline Phosphatase in an asymptomatic Patient. BMJ: 346-48. Doi:http://dx.doi.org/10.1136/bmj.f97 6

Sims, M.S., K.A. Dawson, D.E. Neroman, P. Spring and D.M. Hoogell, 2004. Effects of dietary mannan oligosaccharide, bacitracin methlene disalicylate, or both on the live performance and intestinal microbiology of turkeys. Poult. Sci., 83: 1148-1154.

Talebi A, S. Asri-Rezaei, R. Rozeh-chai and R. Sahraei. 2005. Comparative Studies on Haematological Values of Broiler Strains (Ross, Cobb, Arboracres and Avian). International Journal of Poultry Science, 4 (8): $573-579$.

Thwaites, R. T., and J. A. Frost. 1999. Drug resistance in Campylobacter jejuni, C. coli and C. lari isolated from humans in northwest England and Wales, 1997. J. Clin. Pathol. 52:812-814

Uko, O.J. and AM. Ataja. 1996. Haematological Studies of Pure Indigenous Domestic Fowl (Gallu domesticus) and Guinea Fowl (Numida meleagris) in North Western Nigeria. Revue d'Elevage et de Med. Vet. des Pays Tropicaux, 49:257-262.

Yun, C. H., A. Estrada, A. Van Kessel, B. C. Park, and B. Laarveld. 2003. Beta-glucan, extracted from oat, enhances disease resistance against bacterial and parasitic infections. FEMS Immunol. Med. Microbiol. 35:67-75.

Zduñczyk Z, J. Jankowski and A. Koncicki. 2002. Growth Performance and Physiological State of Turkeys fed Diets with Higher Content of Lipids Oxidation Products Selenium, Vitamin E and Vitamin A. World's Poultry Science Journal, 58 (3): 357 - 364.

Zhang A.W., B.D. Lee, S.K. Lee, K.W. Lee, G.H. An, K.B. Song, and C.H. Lee. 2005. Effects of yeast (Saccharomyces cerevisiae) cell components on growth performance, meat quality, and ileal mucosa development of broiler chicks. Poult. Sci., 84: 1015-1021.

Zilva, J.F. and P.R. Pannall, 1984. Clinical Chemistry in Diagnoses and Treatment, 4th Ed. Lloyd-Luke Medical Books Ltd., London, 185pp. 